\title{
American Messiahs: The Narrative Strategies of FDR and Reagan, 1933 and 1981
}

Theo Zenou

\section{(2) OpenEdition \\ Journals}

Electronic version

URL: https://journals.openedition.org/ejas/15963

DOI: 10.4000/ejas.15963

ISSN: 1991-9336

Publisher

European Association for American Studies

\section{Electronic reference}

Theo Zenou, "American Messiahs: The Narrative Strategies of FDR and Reagan, 1933 and 1981", European journal of American studies [Online], 15-2 | 2020, Online since 23 June 2020, connection on 08 July 2021. URL: http://journals.openedition.org/ejas/15963 ; DOI: https://doi.org/10.4000/ejas.15963

This text was automatically generated on 8 July 2021 .

Creative Commons License 


\title{
American Messiahs: The Narrative Strategies of FDR and Reagan, 1933 and 1981
}

\author{
Theo Zenou
}

1 In July 2012, while running for re-election, President Barack Obama was asked about the biggest mistake of his first term. For a politician on the campaign trail, his reply was surprisingly candid: "The mistake of my first term ... was thinking that this job was just about getting the policy right. ... But the nature of this office is also to tell a story to the American people that gives them a sense of unity and purpose and optimism, especially during tough times." ${ }^{1}$

2 Armed with Obama's insight, this article goes back to two instances of "tough times" in modern American history: the Great Depression and the late 1970s-1980 stagflation. It asks what stories did Franklin D. Roosevelt and Ronald Reagan - the presidents respectively elected to solve these crises - tell the people and why. It looks specifically at the period when they entered office, in 1933 and in 1981, and seeks to illuminate how Roosevelt's and Reagan's stories illustrated their political strategy.

3 No historical analogy is ever perfect, and neither is this article's. While the crises in 1933 and 1981 were both severe, it is obvious they were not on par. The Great Depression devastated the American economy far more than stagflation. And yet, in early 1981, comparisons were drawn between the two. Reagan himself said: "We're in the worst economic mess since the Great Depression." ${ }^{2}$ However tempting it might be to dismiss so dramatic a pronouncement as alarmism serving the president's agenda, it actually reflected a sentiment prevalent at the time. For instance, New York Times economic columnist Leonard Silk wrote that "stagflation threatens America's economic strength as seriously as did depression in the 1930's." ${ }^{3}$ Hindsight now tells us this did not happen. But while history is written with hindsight, it is experienced without. Hence, to many in 1981, stagflation felt like a dangerous crisis that could well spiral into another Great Depression. 
Beyond a dire economy, what made the situation in 1981 similar to that in 1933 was the lack of confidence people had in the future and, crucially, in politicians' ability to make things better. ${ }^{4}$ As Silk reflected when comparing the two periods, "Now, as then ... the nation is plagued by anxiety over its economic future ... a key part of the job of reconstruction will be psychological." ${ }^{5}$ In other words, the role that Reagan would have to play once in office was not so different from the one Roosevelt had played upon ascending the presidency: To reassure and motivate a weary nation. That is why journalists frequently likened the Republican to his Democratic predecessor - a parallel that greatly pleased Reagan. In fact, he had laid the groundwork for it by appropriating Roosevelt's own terminology during the 1980 campaign, leading The New York Times to run a provocative headline that read: "Franklin Delano Reagan." As William E. Leuchtenburg succinctly puts it: "Reagan presented himself as Rooseveltian." 6

rationale for focusing on these two presidents, and the starts of their tenures, also lies in the scholarship of political scientist Stephen Skowronek. According to him, Roosevelt and Reagan were "reconstructive presidents" - meaning presidents elected in volatile times who birthed a new political "regime," and a new political philosophy underpinning this "regime." This article, then, aims to explore the narrative strategies with which these two "reconstructive" presidents opened their time in office.

The argument is that - despite manifold political differences - the stories Roosevelt and Reagan told were similar, and advanced their ambition to transform American politics. The two presidents formulated their stories in the wake of economic crises that had left Americans with little faith in the status quo. Consequently, they bore striking parallels. By way of speeches, Roosevelt and Reagan both depicted America as a land in the grip of blight, ruined by the avarice and duplicity of elites. Men of intense faith, the presidents portrayed themselves as messiahs sent by God to make America rise from the ashes. Ultimately, the presidents both used their stories to signpost the radical change they wished to engender, and shape a new political imagination.

\section{The Literature}

7 In The Power and the Story, Evan Cornog claims "the essence of American presidential leadership, and the secret of presidential success, is storytelling." ${ }^{1}$ Cornog's is the first major work that looks at the U.S. presidency through the lens of political "storytelling." It is panoramic (spanning 43 presidents) and multi-focused (dealing with all kinds of presidential stories from biographies to political and media narratives). Cornog chooses to structure his study according to "the trajectory of an archetypal man of power ... from the politician's first emergence as a public figure through his rise to national prominence, the presidential campaign, the exercise of power, reelection and defeat, and then his efforts to reinterpret and redefine the story until his death." 2 As a consequence, while Cornog offers a systemic interpretation, even a kind of unified field theory, of the presidency along the lines of storytelling, he does not - cannot sharpen his focus to offer in-depth analysis of any single president. The Power and the Story, therefore, leaves plenty of room for more pointed studies like this article's.

8 Following in Cornog's footsteps, other scholars have tackled political storytelling with approaches ranging from the theoretical to the historical. ${ }^{3}$ Those whose work is most relevant to this article are Christian Salmon and Jan Hanska. Salmon has authored a key conceptual text, the monograph Storytelling, in which he details how politicians, 
advertisers and military leaders have used narrative - the "storytelling machine" - to accrue their control over society. He makes no mention of Roosevelt, but he identifies Reagan as a master practitioner of "'narratocracy."' Hanska, meanwhile, explores that narratocracy in Reagan's Mythical America. ${ }^{5}$ His approach differs greatly from that of this article. Broad, he surveys Reagan's entire political career. As such he allows, invites even, approaches that look at a specific period of Reagan's presidency.

Beyond the relatively recent literature concerned with political storytelling, one can also turn to studies of presidential rhetoric for insights into Roosevelt and Reagan. Mary E. Stuckey and Paul D. Erickson are successful in showing how both leaders respectively deployed biblical imagery. ${ }^{6}$ Robert Dallek, meanwhile, provides a strong assessment of Reagan as a leader apt at using symbolism. ${ }^{7}$ However, these scholars unlike this article - do not try to identify overarching "stories" in the presidents' rhetoric, much less during a single, specific period of Roosevelt's and Reagan's tenures: their first months in office.

10 While much has been written about Roosevelt's famed "first hundred days" (March to June 1933), it mostly pertains to policymaking. ${ }^{8}$ A notable exception is David W. Houck's FDR and Fear Itself, which focuses on the inaugural address. ${ }^{9}$ Few studies, meanwhile, have been attempted about Reagan's own "first hundred days"-period, which actually spanned six months (January to July 1981) - the time it took him to launch his presidency, argue for Reaganomics, and achieve enactment of the Economic Recovery Tax Act. ${ }^{10}$

\section{A Note on Theory}

11 Story, narrative, storytelling: These terms originate from the fields of literary/dramatic theory where they have specific, often hotly-debated, meanings. It is worth nothing that, with this article, no attempt is being made to contribute to those fields. Indeed, I am borrowing insights from theory to shine a light on presidential leadership and political strategy, not the other way around.

12 This article defines a political story as the narrative that pervades the public communications of a statesman (speeches, interviews, TV and campaign appearances, etc.). This is in keeping with Roland Barthes' capacious definition of narrative: "Among the vehicles of narratives are articulated language, whether oral or written, pictures, still or moving, gestures, and an ordered mixture of all those substances; narrative is present in myth, legend, fables, tales, short stories, epics, history, tragedy, drame [suspense drama], comedy, pantomime, paintings ... stained-glassed windows, movies, local news, conversation." ${ }^{\prime}$

Roosevelt and Reagan were not only the narrators of their stories; they were also the protagonists at the heart of those narratives, what Hanska calls the "dramatis, or rather the narratis, persona." ${ }^{2}$ By being both in the story and the ones telling the story, Roosevelt and Reagan were thus able not only to propose their own version of events, but also to portray themselves as they wished to be seen.

14 As of the question of authorship - ie. who deserves credit for the presidential narratives: the presidents or their strategists/speechwriters? - this article sides with Hanska when he writes that "in a political narration the narratorship is more important than the origins of the words that combine into a story." ${ }^{3}$ Indeed without the 
narrator-president, there not only cannot be a story, there is also no one to tell that story.

To make a cinematic analogy: Roosevelt and Reagan were the "auteurs" (if not always the writers) of their stories. ${ }^{4}$ This observation was actually made by journalist Sidney Blumenthal, in 1981, when covering the Reagan administration. He surmised that "the former actor is more than White House leading man; he's the auteur." ${ }^{5}$ This article similarly regards presidents as the "auteurs" of their stories - since they are the narrators. And it ultimately draws attention to the way Roosevelt and Reagan used narrative as a tool to fulfil their ambition to transform American politics.

\section{Roosevelt as Messiah}

A narrative reading of Franklin D. Roosevelt's speeches shows that he portrayed himself as a messiah. This might be because, according to Frances Perkins, a close friend as well as political associate, he saw himself as fulfilling God's will. Indeed, Roosevelt believed that he was "an actor placed on the stake [sic] by Divine providence."1 This belief stemmed from his non-dogmatic yet intense faith - one of the hallmarks of the president's character. ${ }^{2}$ Even so, as Gary Scott Smith notes, Roosevelt's piety has seldom been analysed by historians. ${ }^{3}$

17 This might be because, as Andrew Preston remarks in his study of religion in U.S. foreign relations, most "modern historians['] ... worldview is not framed by religious faith." Consequently, scholars have often dismissed politicians' religiosity as having little to no bearing on their policies or decisions. ${ }^{4}$ But in the case of Roosevelt, this is beginning to change thanks to Christine Wicker. She holds that the president's "worldview and much of his personality was shaped by the strength and vibrancy of his Episcopal faith, which was fed by his sense of a continuing relationship by God." Elsewhere, Wicker writes plainly that "he believed God communicated with human beings, himself in particular."

On the morning of his inauguration on March 4, 1933, Roosevelt attended services at St. John's Church along with members of his inner circle. The rector had written a special hymn for the new president, beseeching God for "Thy blessing upon Thy servant, Franklin." The story he told the American people would indicate that - as Perkins revealed - Roosevelt did share the sentiment prevalent in the prayer. Indeed, he sought to become a kind of American prophet, a redeemer with the necessary inspiration to revive sacred values and place them at the heart of society. Roosevelt cast himself in the halo of the spiritual repeatedly. The most direct evidence of this can be found in his proclamation that he was ordaining an assembly of "prophets of a new order." $\mathrm{He}$ labelled his policies a "common covenant," of which he was the keeper, and he urged the American people to keep the faith despite the criticisms or fabrications - in other words the heresy - they might hear about Roosevelt's plans. ${ }^{8}$

Scholars have long tiptoed around the argument that Roosevelt depicted himself as messiah. Gary Scott Smith contends that Roosevelt "frequently asserted that God directed history, considered himself to be God's agent" adding that he "saw himself as carrying out God's purposes." Smith stops short, however, of following through on the messianic implications of his observation. Mary E. Stuckey does but then dismisses them, stating that "while the president employed rhetoric that enabled such [messianic] associations, he was more likely to assume the role of preacher than of 
biblical character." ${ }^{10}$ But Moses and Jesus, the biblical characters to whom she is referring, were also preachers. ${ }^{11}$ In the biblical tradition, most prophets are preachers, even if the opposite is not so. In the framework of his story, Roosevelt was both preacher (narrator) and prophet ("narratis persona"). The president's messianism was deftly woven through the story, hinted at rather strongly but never expressed in such outright terms as to become boastful or, worse, clumsy. Raymond Moley, who wrote the bulk of Roosevelt's inaugural address, certainly seemed aware of the prophetic parallels evoked by that speech. ${ }^{12}$

One way for Roosevelt to present himself as a messiah was to make biblical references, widely known in society, and using them as shorthand for characterisation. A memorable instance can be found in Roosevelt's inaugural address. The president described the American elites - the bankers and politicians whom he held responsible for the Great Depression - as the "money changers ... in the temple of our civilization." ${ }^{13}$ As has already been noted by Ronald Isetti in an article exploring Roosevelt's religious language, this alluded to an episode in the New Testament in which Jesus casts out the wicked merchants from the temple's courtyard. ${ }^{14}$ But Roosevelt did more than simply infuse his rhetoric with the vernacular of scripture.

Indeed, his very story played out like a modern re-telling of Biblical myths, all leading to the inevitable portrayal of Roosevelt as the anointed one. He depicted America as a land ruined by the avarice of self-seeking elites and the hypocrisy of "false" leaders..$^{15}$ They were personified as "false prophets" that had led "many amongst us [to] have made obeisance to Mammon." ${ }^{16}$ Darkness engulfed the country, and the people were crying out for a saviour. ${ }^{17}$ The people, Roosevelt proclaimed, had "to seek new leaders of our own choosing." ${ }^{18}$ To quote an aide of the new president, "the stage was obviously set for the entry of ... Roosevelt as the hero of the new drama." ${ }^{19}$ Indeed, against this grim backdrop, an age-old battle - in narrative terms a conflict - was being waged, juxtaposing the forces of good and evil. Roosevelt, as Stuckey observes, frequently resorted to Manichean oppositions over his twelve-year presidency. ${ }^{20}$ And at the start, it was to castigate the "evils of the old order" and contrastingly exalt his brand of righteous leadership.

Moreover, part of Roosevelt's political playbook was to have avowed enemies. ${ }^{21}$ It was also an important device in his story. Repeatedly, he accused the members of the old order - though he seldom referred to them by their actual names - of engendering the demise of America. They were labelled blind whilst Roosevelt had vision, selfish whilst he was selfless, venal whilst he was ethical. ${ }^{22} \mathrm{He}$ strongly hinted they were foul when he insisted his party was the one with "clean hands." ${ }^{23}$ Even once he was in office, Roosevelt continued to narrate this high-stakes conflict, although, by then, most likely because he was no longer campaigning, his antagonists had become more abstract. In his inaugural, the president famously proclaimed that "the only thing we have to fear is fear itself," subsequently turning "the phantom of fear" into the people's ominous adversary. ${ }^{24}$

Historians have remarked that, in 1933, Roosevelt described the Great Depression as a war, and the narrative reading of the president as messiah means this war carried spiritual connotations. William E. Leuchtenburg was the first to notice this allegory of the Depression as war. ${ }^{25}$ It was not a metaphor but an apt description of reality for many Americans. As Leuchtenburg argues - and this statement also applies to the reasoning behind this article - "the metaphors a nation employs reveal much about 
how it perceives reality. The words people use bare the bedrock of its beliefs. Moreover, they are not neutral artifacts; they shape ideas and behavior." ${ }^{26}$ Roosevelt, it would seem, was very much aware of this. He made his martial leadership explicit when he affirmed that "I assume unhesitatingly the leadership of this great army of our people dedicated to a disciplined attack upon our common problems." ${ }^{27}$ He frequently extolled military values, most notably the merits of discipline, commitment to the mission and loyalty to the group. Roosevelt put military language in the service of his messianic story. He presented his campaign, and by inference his presidential mandate, as more than political. It was, in his words, "a call to arms ... [a] crusade" he was to lead. ${ }^{28}$

And only a week after assuming power, he used narrative to influence reality. In his first fireside chat, Roosevelt spoke like a general commanding his troops. The mission was simple. Due to overwhelming cash withdrawals, he had ordered the closure of all banks to stabilise the market. They were to re-open, however, to enable economic recovery. Yet, for this plan to succeed, it was paramount that ordinary Americans deposit their cash back into the very banks they had thought insolvent. After laying this objective starkly - and explaining why the course of action was sound - Roosevelt urged, in essence, for his foot soldiers to obey his orders unquestioningly, and do so for the good of the nation. ${ }^{29}$ Perkins observed that the president's "quality of being one with the people" - in other words, his convincing show that he was speaking on their behalf, that he was being literally their spokesman - "made it possible for him to be a leader without ever being ... a dictator." ${ }^{30}$ The people, after all, were the flock Roosevelt's messianic protagonist was to lead to the promised land.

If the Moses-like interpretation of Roosevelt appears far-fetched by today's standards, a portion of the American people, in 1933, actually believed in it. The flurry of letters mailed to the White House during the first hundred days was unprecedented in the history of the presidency. ${ }^{31}$ Many of these letters were not concerned with policy but were, instead, emotional reactions to Roosevelt's story. The letters were tinged with spiritual connotations. Writing after the first fireside chat on banking, one woman wrote that in the years previous America had "lost [its] soul." The people had "cried for a Leader." And, according to her, out of this misery Roosevelt had emerged as "the passionate ... crusader." She ended her letter by sharing her view of Roosevelt as "Leader." Indeed, she suggested that he was not only the people's president, but also God's president. In fact, to her, they were one and the same, as she professed to believing that "the voice of God was the voice of the people last November," referring to the presidential election. ${ }^{32}$ Another ordinary citizen literally compared Roosevelt to the prophets he had, in his story, modelled himself after but never outrightly named:

After listening to your wonderful talk Sunday a week ago - we all felt ... that you were sent for our delivery. When in times of deep distress God took pity on His people. He sent Moses to deliver the oppressed. Then He sent Jesus Christ - to show His people how to live - to redeem them - Then you a Comforter to put confidence in this so great a people. ${ }^{33}$

Some Americans, then, perceived Roosevelt as a messianic figure. When examining letters from the public to Roosevelt (in this case during a longer period from 1933 to 1936), Isetti found that his supporters often compared the president to Moses, with one woman claiming that God had sent him "to deliver us from the hands of the oppressors as truly as He did Moses." ${ }^{\prime 34}$ This image of Roosevelt as a divine agent was pervasive enough that in December 1933, at the annual meeting of the Protestant Episcopal Church's New York Diocese, a reverend felt the need to state on the record that 
Roosevelt was not a messiah. The man of God expressed his genuine disgust "at the baselessness of this pathetic and pitiful superstition," which, he deplored, was nonetheless espoused by "thousands of men." 35

It is unknown to what extent the White House reflected on these reactions to their story, but officials knew of the quasi-religious devotion their story had engendered, particularly amongst the most disfranchised classes. In 1934, Harry Hopkins, then administrator of the New Deal's Federal Emergency Relief Association, hired a team of journalists to investigate poverty in the country. ${ }^{36}$ Among them was future star journalist Martha Gellhorn. Her reports were impressionistic dispatches from an America hit hard by the Great Depression. The young reporter meticulously documented her interactions with those people who saw themselves as living embodiments of Roosevelt's "forgotten man." With each story Gellhorn related, the president emerged more and more as a figure of intense popular worship, the subject of an emotional phenomenon that bordered on the religious. Indeed, in a report of November 11, 1934, Gellhorn revealed to Hopkins that she heard someone say, with earnestness and gravity: "We trust in the Supreme Being and Franklin Roosevelt." ${ }_{37}$

Similarly, in her study of religiosity in the Depression-era South, Alison Collis Greene writes that for many people in those days, "it was time for a higher power to intervene. They looked to God, and then they looked to Roosevelt." ${ }^{38}$ For some, it seemed that the president's power was divinely sanctioned. The primary role of (his) government was to accomplish, under his stewardship, God's work on Earth. After all, the opening line of his inaugural address - which Roosevelt had added himself at the last minute - was: "This is a day of national consecration." According to Houck, that is because the soonto-be president had "wanted something to mark this moment as sacred, ordained by [God] ... God should be invoked from the outset of his administration." ${ }^{39}$

In a report dated April 25, 1935, Gellhorn observed that many she encountered had an "almost mystic belief in Mr. Roosevelt"40 This "belief" - what the Episcopalian reverend had called a "superstition" - was no accident: Roosevelt's story had had a lot to do with it (and presumably, of course, so did other factors such as the New Deal's relief programmes). It all pointed back to the president's self-characterisation as a prophetic figure - one that stemmed from his conviction he had been chosen by providence to lead America out of the Great Depression. In his speeches, he had systematically and consistently explained the Depression by telling a story. He presented America as laden with sin, and the political and financial classes as crass worshippers of Mammon - one of the princes of hell. In contrast, he portrayed himself as a messiah sent by God to purge America and lead the people to greener pastures. To tell this story, Roosevelt drew primarily on the Bible, which he knew intimately, although he cared little about nuances of theology and interpretation. ${ }^{41}$ What mattered was the story.

\section{Reagan as Messiah}

A narrative reading of Ronald Reagan's speeches shows that, just like Roosevelt, he presented himself to the American people as a messiah. It seems, too, that his rationale was the same as Roosevelt's. Reagan was also a believer and faith played an important part in his life, even if he wasn't a regular church-goer. As H.W. Brands notes: "[Reagan] explained that his attendance disrupted the [church] services, which was true enough. But his faith was internal rather than institutional." Indeed the 
president's religiosity was idiosyncratic, albeit anchored in Christianity. He thought that the Bible contained the solutions to all man-made issues. ${ }^{2}$ Jesus Christ was the individual he most admired. ${ }^{3} \mathrm{He}$, too, felt he had a special relationship with God, to whom he referred as "the man upstairs." In fact - following the attempt on his life of March 30, 1981 - Reagan believed he had been spared for a reason, so he could pursue a divine will. ${ }^{4}$

His story, nonetheless, already had hues of the spiritual before this sombre episode. He wished to "renew the American spirit and sense of purpose," as he said in his acceptance address at the 1980 Republican national convention. ${ }^{5}$ For Michael Deaver, his deputy chief of staff, faith was Reagan's principal "source of inspiration." ${ }^{6}$ It was also the fundamental attribute he urged Americans to find in themselves, in others and indirectly in his leadership. ${ }^{7}$ Just as Roosevelt promised Americans that the Great Depression could teach them a lesson about service, Reagan pleaded for them to believe that the country's difficulties also had a redemptive purpose. ${ }^{8}$ Tragedy, in his mind, could beget transcendence.

Scholars have correctly identified that Reagan depicted himself as a "political messiah" who would bring back hope and prosperity to his country. ${ }^{9}$ This article shows that, whilst Reagan did portray himself as a messianic protagonist, he was subtler and less strident than Roosevelt in doing so - which might be explained by the context of his times. ${ }^{10}$ Still his language and self-characterisation came close to Roosevelt's, and depicted the Republican as having the necessary traits of a messiah. For instance, Reagan emphasised his almost supernatural sense of vision, his ability to perceive what others did not. "Some say that spirit no longer exists," he lamented. "But," he added, "I have seen it - I have felt it - all across the land [emphasis mine]." ${ }^{11}$ In saying this, Reagan differentiated himself not only from other politicians but also, quite literally, from most other Americans. He could see, more importantly feel, things no one else did. Armed with his unique insight, Reagan invited the people to join him on a "crusade" - just as Roosevelt had done 48 years prior when he too accepted his party's presidential nomination. For Reagan, as he said upon accepting the Republican nomination in 1980, the "crusade" was "to make America great again." For Roosevelt, it had been to "restore America to its own people." ${ }^{12}$ In this crusade, Reagan identified as the most important weapons not "'bombs and rockets' but belief and resolve." ${ }^{13}$ Faith, in other words, was all that was needed to win.

Reagan, like Roosevelt, relied on the vocabulary of populism to depict his antagonists as wicked - and thus contrast himself as a messianic protagonist. As Michael Kazin observes, Reagan, borrowing from Roosevelt, claimed he was on the side of common folk against political elites. ${ }^{14}$ For both presidents, populism was a natural and logical strand of their story - a way to build upon their messianism. They presented themselves as anointed saviours who would lead the people to newfound success. It begged one question: who did the people need saving from? Populist rhetoric offered the answer. By adopting the "us vs. them" structure of populism, Roosevelt and Reagan were able to zero in on the antagonists of their story. Although they did not have the same antagonists - Roosevelt leaned towards blaming corporate America, whilst Reagan was a staunch critic of government bureaucracy - both men shared a common enemy: the political class. inhumane, profligate and reckless. ${ }^{15}$ They were double-faced liars who had betrayed the 
sacred trust of the people. They had taken advantage of their good will, demanding more and more of their hard-earned money to keep alive a bloated system. Their cardinal sin - in other words the grave misdeed committed by Reagan's antagonists was "a theft from [the people's] pocketbooks." ${ }^{16}$ In so doing, they had stripped America of its greatness, making it feeble and leaving its citizens "frustrated and ... a little afraid." ${ }^{17}$ In contrast, as protagonist, Reagan stood for candour and a spirit of sincerity in all things. He consistently emphasised he spoke the truth, even if it was not an uplifting one. As a messenger, he refused to be a false prophet, one who "said, 'Trust me," but ignored the harm he caused. ${ }^{18}$ Although he promised to improve the country's situation, he confessed it would not be easy. ${ }^{19}$ Reagan presented himself as a reliable truth-teller, unafraid to emphasise the difficulties and challenges that would arise. That is why he spoke of "regret[ting] to say" the country was in an economic maelstrom, of being "afraid [his] message ... was grim and disturbing." ${ }^{20} \mathrm{He}$ recognised he "painted a pretty grim picture," but insisted it was only a mirror of reality. ${ }^{21}$ Whilst both are remembered as optimists, Reagan could have been channelling Roosevelt who had made a similar point amidst crisis, conceding that "only a foolish optimist [could] deny the dark realities." ${ }^{22}$ It was against this similarly ominous backdrop that Reagan could starkly define the conflict of his story. He symbolised it as the choice between two roads. It is worth considering his own words in context here:

One road is all too familiar to us. It leads ultimately to higher taxes. It merely brings us full circle back to the source of our economic problems, where the government decides that it knows better than you what should be done with your earnings and, in fact, how you should conduct your life. The other road promises to renew the American spirit. It's a road of hope and opportunity. It places the direction of your life back in your hands where it belongs. ${ }^{23}$

Reagan portrayed himself as a liberator, granting freedom to a people held captive by an oppressive and ubiquitous government, the very government that he famously lambasted as "in this crisis ... not the solution [but] ... the problem." ${ }^{24}$ Richard Wirthlin, his pollster and strategist, observed that the president spoke of liberty as a gift that could only be bestowed by the grace of God..$^{25}$ And yet in his story, Reagan suggested his command would give America back its freedom. His programme was about a "vision of society that frees the energies and ingenuity of our people." ${ }^{26}$ His leadership was about granting a new "compact of freedom" to the people - a sort of covenant between them and him..$^{27}$ Therefore, although for Reagan liberty came from providence, he was the intermediary that made this divine endowment even possible. In the context of his story, he did so by getting Americans to "believe" once again. As a protagonist, he therefore fulfilled - in the same manner as Roosevelt - the basic tenet of the messiah. He got the people to rekindle their faith. As Reagan later put it in his memoirs, his first and foremost objective had been to "bring about a spiritual revival in America." ${ }^{28}$ But what exactly did he mean by this?

According to Gary Scott Smith, in 1983, two years after he entered office, Reagan detailed the "spiritual awakening and moral renewal" that the country was undergoing. He rejoiced in surveys showing a great majority of Americans disapproved of promiscuity and drug use, opposed abortion, and extolled family values and religious faith. ${ }^{29}$ But Reagan's definition of a "spiritual revival" did not limit itself to championing the conservative values of God and country. It primarily meant restoring the people's faith in America itself and its "unique sense of destiny." They had been lost, Reagan believed, since his predecessor Jimmy Carter had presided over a 
weakening of the nation's moral fibre. ${ }^{30}$ Thus, Wirthlin's campaign plan advised Reagan to integrate "a morale-building element" to his "leadership," pointing to the presidencies of Roosevelt and John Kennedy as inspirations. ${ }^{31}$

Reagan's "spiritual revival," then, had an ineffable quality to it. He saw it as mystical. This is why, writing in 1982, barely a year into Reagan's first term, Garry Wills ironically dubbed his presidency the "papal presidency." "His appeal is not to reason but to faith, to his vision of America as an infallible mother church." ${ }^{32}$ Wills implied that Reagan was a leader animated by a naïve faith, and that this faith was in fact all he really offered the people. As such, much like the pope, the president became a spiritual leader rather than a squarely political one.

For Reagan but also for Roosevelt, the messianic overtones of their stories dovetailed with the concept of American civil religion. As Robert Bellah explains: "Behind the civil religion at every point lie biblical archetypes: Exodus, Chosen People, Promised Land, New Jerusalem, Sacrificial Death and Rebirth." Indeed American civil religion, though distinctive and distinctly American, relies on universal motifs, namely religious ones. "It is," according to Bellah, "an understanding of the American experience in the light of ultimate and universal reality." ${ }^{33}$ But, with their stories, the two presidents did more than implicitly rely on American civil religion. They also strengthened it. By depicting America as a land needing divine intervention, and portraying themselves as the agents of that intervention, Roosevelt and Reagan stressed the trope, so key to American civil religion, that the U.S. was special and set apart by God. And that prosperity would come about when God's will was finally carried out in the nation's politics.

\section{Story as Political Strategy}

In 1933 and in 1981, Roosevelt and Reagan both presented themselves as modern messiahs operating in conflicted times, times they depicted as rife with spiritual malaise. The two presidents proclaimed a crusade to right society's wrongs. But what were the presidents hoping to achieve by telling these stories? ${ }^{1}$ On a basic level, of course, they were hoping to successfully launch their presidency. Yet, as has been hinted at throughout this article, their ambition ran much deeper.

Both presidents looked to reinvent the political imagination of their day. They wanted to change political ethos. Telling a story was a strategy to fulfil this lofty ambition. (Whether or not one considers they did so is irrelevant to the claim that storytelling was a way in which they tried to.) The focus here is on proving intent, not assessing effect or substantiating a result. And Roosevelt and Reagan both intended to change the assumptions around which American politics revolved. But first, it is necessary to ask why telling a story would even contribute to this end. In other words, how does story help develop new political ideas?

41 Stories are a way to hold the public's attention. In 2004, a Democratic "spin doctor" was asked why his party had lost the presidential election. His reply was succinct: "They [the Republicans] produced a narrative, we produced a litany." What he implied is that whilst Democrats ran on the issues, Republicans framed these issues around a narrative. As he put it: "They say, 'I'm going to protect you from the terrorists in Tehran. ... We say, 'We're for clean air."' ${ }^{2}$ Roger Stone, the political strategist whose career includes work for Reagan campaigns, made a similar point: "Put out a white paper on your environmental positions, you will bore [everyone] ... no one will pay 
attention." ${ }^{3}$ But while it is easy to see how political storytelling can grab people's attention, why would it also help to spread ideas to the public?

According to Roland Barthes, that is because story is a "cognitive category" that enables humans to comprehend the world they live in. ${ }^{4}$ For Hayden White, "narrative is a meta-code, a human universal on the basis of which transcultural messages about the nature of a shared reality can be transmitted." ${ }^{5}$ But perhaps no one has put it better or rather surmised the connection between stories and human beings better - than evolutionary psychologist Jonathan Gottschall: "[We are] the primate Homo fictus (fiction man), the great ape with the storytelling mind."' Storyteller and film historian Martin Scorsese goes further. He argues that stories "fulfil a spiritual need that people have: to share a common memory."

If Scorsese's pronouncement of a "common memory" sounds like it could have been made by Roosevelt or Reagan, given the way that they have been discussed so far, it is because they shared the sentiment. Roosevelt felt he had a grasp, in his words, of "a strange and weird sense known as "public psychology."'8 It seems to have been a mix of intellect and intuition - what Reagan called a "feel" - that enabled both men to get a sense of what people were thinking, and the kind of ideas to which society would be receptive. ${ }^{9}$ To be sure this was only one of the many ways they did so. However, in regard to their perception of public psychology, it is worth noting that both men exchanged letters with ordinary citizens. A perusal of Roosevelt's speech files shows that he received suggestions and ideas from segments of the American public. Reagan, meanwhile, spent a considerable amount of time exchanging letters or telephone calls with ordinary Americans. ${ }^{10}$ It was a way for them, in show business parlance, to "know their audience."

Both Roosevelt and Reagan, moreover, understood the emotional power stories had over the public's psychology. During the transition period, Roosevelt actually contributed to a film titled Gabriel over the White House (1933). It was conceived as a vehicle advertising the merits of an activist presidency. The film's fictional president bore strong similarities with Roosevelt, which critics did not fail to notice. The plot focused on that president's attempt to solve the Great Depression, and his transformation into a literal messiah after he is visited by the archangel Gabriel, leading him to carry God's will on earth. Roosevelt provided extensive notes on the script, and advised on the final edit. He later thanked the film's financier, William Randolph Hearst, for an engaging film that "should do much to help." ${ }^{11}$ The implication was clear. Roosevelt felt that Gabriel over the White House would contribute to advancing not only his agenda, but also furthering his standing as a new president. This illuminates his thinking at the time that this article covers. And although Roosevelt would most likely not have used the term political storytelling - it is only very recent he certainly understood the power of story, and the role it played in promoting his politics. Interestingly, earlier in his life, Roosevelt had also tried his hand at scriptwriting. ${ }^{12} \mathrm{He}$ had a demonstrable interest in the craft of narrative, hiring dramatists Orson Welles and Robert E. Sherwood to serve as speechwriters.

In Reagan's case, storytelling was not only his enduring passion, but also the way he viewed the world. In his youth, Reagan "recreated" baseball on the radio. Sitting in a studio, he was wired three-character summaries of the game, play by play. He had to use his imagination to fill in the gaps, keeping listeners hooked by telling a story about a game he knew almost nothing about. One day, the wire broke midway during a game. 
Untroubled, Reagan simply continued narrating the game, literally inventing it. Of his stint as a sportscaster, Reagan said: "Making things up. Mixing fact and fiction. [Pause]. What great preparation for politics." ${ }^{13}$ Later, Michael Deaver, White House deputy chief of staff, explained that the president thought in terms of film plots, often justifying his decisions according to character and scenes from his own Hollywood pictures. ${ }^{14}$ Journalist Frances FitzGerald surmises that many collaborators depicted him "as living in a world of rhetoric, performances and perception" detached from facts. ${ }^{15}$ George Shultz, Reagan's Secretary of State, explained this in powerful and evocative terms:

Sometimes President Reagan did not seem to care that much about facts ... and it bothered me. On occasion, I would try to correct the inaccurate chronology of a favorite story about something he had done earlier in the presidency. ... He nodded in agreement and kept right on telling the same story. ... Over time, I began to see another side to his love of storytelling: he used a story to impart a larger message and sometimes that message was simply more important to him than the facts.... People, he felt, believe in and act on the stories they hear and tell about the past. Stories create meaning. ... To Ronald Reagan, today's events always seemed rooted in ... some story he had incorporated long ago. ${ }^{16}$

\section{Story as a Tool of Transformation}

The stories of Roosevelt and Reagan both imparted a larger message: change was coming. In depicting themselves as messiahs, they gave this change a redemptive quality. They would, in fact, save the nation from the crisis befalling it, and instil new values. These new values resulted from the radical re-thinking of political orthodoxies that Roosevelt and Reagan advocated. Beyond the examples highlighted in their speeches, their collaborators attested to their transformative ambition - the end goal of their stories.

Perkins remembered Raymond Moley's reaction after Roosevelt's inaugural address. Moley was one of the president's oldest aides and a close advisor. (In Reagan's time, he would have been called a strategist.) Moley had contributed to the text of the inaugural but, upon hearing it, he soon realised that Roosevelt had made considerable edits. They were all about fundamentally changing the role of government. Overwhelmed with angst because of the sheer breadth of the change Roosevelt was talking about, he turned to Perkins. "Well," he said in a state of exasperation, "he's taken the ship of state and he's turned it right around. We're going in the opposite direction."

of Reagan, Wirthlin said in no uncertain terms that "he had entered office with a mission. ... He hadn't sought the presidency for fame or fortune. ... No, Reagan wanted to be president for a simple reason: he wanted to transform the world. He wanted to reshape the way future Americans would live." ${ }^{2}$ Wirthlin's comment was not just an attempt at legacy-building years after the fact, a nostalgic homage to his mentor.

Indeed, internal White House documents from January 1981, when Reagan launched his presidency, show that the president and his team were already definite about their desire to profoundly alter America. According to Gil Troy, "[the president's] aides understood that mandates were construct." Theirs was certainly ambitious. ${ }^{3}$ In a presidential briefing given five days before the inauguration, the following points were made. First, "Reagan's mandate is "change." The 1980 election which had seen him triumph two months before was described as "an axial event demarking a major political opportunity." It was not a mere "bestowal of power," but rather a 
"stewardship opportunity for us to reconsider and restructure the political agenda for the next two decades." The conclusion was unambiguous: "The public has sanctioned the search for a new public philosophy to govern America." ${ }^{4}$ Reagan's conservative philosophy would be the answer.

The Reagan administration connected their transformative ambition to Roosevelt. In preparation for the president's first State of the Union, Richard S. Beal, director of the Office of Planning and Evaluation, reviewed all similar messages given by predecessors. On Roosevelt's first State of the Union, Beal aptly summarised the spirit of the address as being "no return to the old ways; must go forward to make economic and social structure capable of dealing with modern life." He concluded his analysis with a succinct but admiring assessment: "people behind FDR; a new era." ${ }^{5}$ In so doing, Beal demonstrated the Reagan administration's historical understanding of Roosevelt as a transformative president. And given its own mission statement to present "a new public philosophy to govern America," it was clear they hoped President Reagan would be every bit as transformative. For Reagan, just like Roosevelt before him, telling stories to the American people was a way to bring about that transformation.

\section{Acknowledgements}

51 I'd like to thank Dr Frank Gerits, senior editor of the European Journal of American Studies, and two anonymous reviewers for their guidance and feedback on the article. I'm also grateful to Professor Robert Mason and Dr Fabian Hilfrich for their insightful comments on earlier drafts of this piece, and to Professor Andrew Preston for enlightening conversations. Many thanks as well to archivists Dara Baker (FDR Library), Jennifer Newby and Cole Puente (Reagan Library) for helping me locate primary sources. Lastly, I'm grateful to the School of History, Classics and Archaeology at the University of Edinburgh for an award that partly funded this research.

\section{NOTES}

1. Quoted in Lindsey Boerma, "Obama Reflects on His Biggest Mistake as President," CBS News, 12 July 2012.

2. Ronald Reagan, "Address to the Nation on the Economy," 5 February 1981, The American Presidency Project.

3. Silk did recognize that, nonetheless, the "present situation is not as grim and urgent" as the Depression, but feared it could, and would, worsen. See Leonard Silk, "Reagan: Can He Cure Stagflation?," The New York Times, 11 January 1981, NE1.

4. In 1981 Americans' lack of trust in government was not only due to stagflation and President Carter's underwhelming tenure, but also to prior events in the 1970s that remained scars on the national psyche (notably Watergate and the Vietnam debacle).

5. Silk, "Reagan."

6. Leuchtenburg, In the Shadow of FDR: From Harry Truman to Ronald Reagan (Ithaca: Cornell University Press, 1983), 201, 225. 
7. Stephen Skowronek, "Presidential Leadership in Political Time," in Presidential Leadership in Political Time: Reprise and Reappraisal (Lawrence: University Press of Kansas, 2008), 27-78.

1. Evan Cornog, The Power and the Story: How the Crafted Presidential Narratives Has Determined Political Success from George Washington to George W. Bush (New York: The Penguin Press, 2004), 1.

2. Ibid., 9.

3. See Pere Franch, "Praising the Fallen Heroes: Storytelling in US War Presidential Rhetoric, from Johnson to Obama" Language and Literature, Vol. 27, No. 4 (2018), 311-328; Andrew Leslie, "How Stories Argue: The Deep Roots of Storytelling in Political Rhetoric," Storytelling, Self, Society, Vol. 11, No. 1 (Spring 2015), 66-84; Francesca Polletta, It Was Like a Fever: Storytelling in Protest and Politics (Chicago: University of Chicago Press, 2006); Francesca Polletta, "Characters in Political Storytelling," Storytelling, Self, Society, Vol. 11, No. 1 (Spring 2015), 34-55.

4. Christian Salmon, Storytelling: Bewitching the Modern Mind, trans. David Macey (London: Verso, 2017), 90.

5. Jan Hanska, Reagan's Mythical America: Storytelling as Political Leadership (New York: Palgrave Macmillan, 2012).

6. Mary E. Stuckey, The Good Neighbour: Franklin D. Roosevelt and the Rhetoric of American Power (East Lansing: Michigan State University Press, 2013); Paul D. Erickson, Reagan Speaks: The Making of an American Myth (New York: New York University Press, 1985).

7. Robert Dallek, Ronald Reagan: The Politics of Symbolism (Cambridge: Harvard University Press, 1984).

8. Besides Jonathan Alter, The Defining Moment: FDR's Hundred Days and the Triumph of Hope (New York: Simon \& Schuster Paperbacks, 2007) - a narrative account which recounts Roosevelt's fireside chats - other studies focus on how the first hundred days witnessed the foundation of the New Deal. See Anthony Badger, FDR: The First Hundred Days (New York: Hill and Wang, 2008); Adam Cohen, Nothing to Fear: FDR's Inner Circle and the Hundred Days that Created Modern America (New York: Penguin Books, 2009).

9. David W. Houck, FDR and Fear Itself: The First Inaugural Address (College Station: Texas A\&M University Press, 2002).

10. Leuchtenburg covers such ground in his analysis of Roosevelt's influence on modern presidents - looking specifically at the press coverage Reagan received during the period. See Leuchtenburg, In the Shadow of FDR, 228-232.

1. Roland Barthes, "An Introduction to the Structural Analysis of Narrative," trans. Lionel Duisit, New Literary History, Vol. 6, No. 2 (Winter 1975), 237.

2. Hanska, Reagan's Mythical America, 27.

3. Ibid., 32 .

4. In film studies, the "auteur theory" developed by Cahiers du Cinéma critics holds that, while filmmaking is a collaborative process, the director is the film's auteur (French for "author") even if he is not its writer, as he's the one ultimately telling the story.

5. Sidney Blumenthal, "Marketing the President," New York Times Magazine, 13 September 1981,

1. Oral History interview with Frances Perkins (1951-1961), Notable New Yorkers, part IV, p. 29, Columbia Center for Oral History Archives, Rare Book \& Manuscript Library, Columbia University in the City of New York.

2. The fervour of his faith is not the best-known fact about Roosevelt, perhaps because he was private about his religious beliefs. But faith was an important driving force of his leadership. See Thomas H. Greer, What Roosevelt Thought: The Social and Political Ideas of Franklin D. Roosevelt (East Lansing: The Michigan State University Press, 1958), 3-6.

3. Gary Scott Smith, Faith and the Presidency: From George Washington to George W. Bush (Oxford: Oxford University Press, 2006), 192.

4. Andrew Preston, Sword of the Spirit, Shield of Faith: Religion in American War and Diplomacy (New York: Anchor Books, 2012), 157. 
5. Christine Wicker, The Simple Faith of Franklin Delano Roosevelt: Religion's Role in the FDR Presidency (Washington, DC: Smithsonian Books, 2017), 3, 6.

6. Oral History with Perkins, part IV, pp. 16-18.

7. Franklin D. Roosevelt, "Address Accepting the Presidential Nomination at the Democratic National Convention in Chicago," 2 July 1932, The American Presidency Project.

8. Franklin D. Roosevelt, "Fireside Chat (Recovery Program)," 24 July 1933, The American Presidency Project; Franklin D. Roosevelt, "Fireside Chat on Banking," 12 March 1933, The American Presidency Project.

9. Smith, Faith and the Presidency, 192, 219-220.

10. Mary E. Stuckey, The Good Neighbor: Franklin D. Roosevelt and the Rhetoric of American Power (East Lansing: Michigan State University Press, 2013), 35.

11. Moses sermonised the Hebrew people, in the Book of Deuteronomy, before they entered the promised land. Jesus, called "rabbi" multiple times in the Gospel, delivered his teachings through a famous Sermon on the Mount.

12. Houck, FDR and Fear Itself, 68-70.

13. Franklin D. Roosevelt, "Inaugural Address," 4 March 1933, The American Presidency Project.

14. Ronald Isetti, "The Moneychangers of the Temple: FDR, American Civil Religion, and the New Deal," Presidential Studies Quarterly 26 (1996), 680.

15. Roosevelt, "Inaugural Address."

16. Roosevelt, "Address Accepting the Presidential Nomination."

17. Roosevelt, "Inaugural Address."

18. Roosevelt, "Address Accepting the Presidential Nomination."

19. Donald R. Richberg, My Hero: The Indiscreet Memoirs of an Eventful but Unheroic Life (New York: G.

P. Putnam's Sons, 1954), 153.

20. Stuckey, The Good Neighbor, 47.

21. This observation was actually made by Texas Governor John Connally to President Richard Nixon. See Leuchtenburg, In the Shadow of FDR, 172.

22. The conflict between blindness and vision is particularly important, because the latter is key for a messiah. In a well-known episode of the New Testament (Matthew 9:28 and 9:29) Jesus cures two blind men. This is the connotation that accompanied Roosevelt's paraphrasing of Proverbs 29:18 that "where there is no vision the people perish." The hint was that he had the vision to bring the people back to life. See Roosevelt, "Inaugural Address."

23. Roosevelt, "Address Accepting the Presidential Nomination."

24. Roosevelt, "Inaugural Address"; Roosevelt, "Fireside Chat on Banking."

25. William E. Leuchtenburg, "The New Deal and the Analogue of War," in The FDR Years: On Roosevelt and His Legacy (New York: Columbia University Press, 1995), 35.

26. Ibid., 36.

27. Roosevelt, "Inaugural Address."

28. Ibid.

29. Roosevelt, "Fireside Chat on Banking."

30. Frances Perkins, The Roosevelt I Knew (New York: The Viking Press, 1946), 72-73.

31. Anthony Badger, FDR: The First Hundred Days (New York: Hill and Wang, 2008), xi.

32. Letter, Marie Berrell to Franklin D. Roosevelt, 13 March 1933; Folder: 200B Public Reaction 3/13/33 B-J; PPF 200 Public Reactions Letters; The President's Personal File; Franklin D. Roosevelt Library, Hyde Park, New York.

33. Letter, J. R. Adams to Franklin D. Roosevelt, 13 March 1933; Folder: 200B Public Reaction 3/13/33 A-B; PPF 200 Public Reactions Letters; The President's Personal File; Franklin D. Roosevelt Library, Hyde Park, New York. 
34. Isetti, "The Moneychangers of the Temple," 687-688, quote 688.

35. Quoted in "Holds Roosevelt Is Not a Messiah," The New York Times, 6 December 1933, 20.

36. Rachel Arons, "Chronicling Poverty with Compassion and Rage," The New Yorker, 17 January 2013.

37. Martha Gellhorn to Harry Hopkins, "Report to Mr. Hopkins," 11 November 1934; Folder: FERA Narrative Field Reports; Box 60, The Papers of Harry L. Hopkins; Franklin D. Roosevelt Library, Hyde Park, New York.

38. Alison Collis Greene, No Depression in Heaven: The Great Depression, the New Deal, and the Transformation of Religion in the Delta (New York: Oxford University Press, 2016), 2.

39. Houck, FDR and Fear Itself, 140.

40. Martha Gellhorn to Harry Hopkins, "Re. Camden, N.J.," 25 April 1935; Folder: FERA Narrative Field Reports; Box 60, The Papers of Harry L. Hopkins; Franklin D. Roosevelt Library, Hyde Park, New York.

41. Perkins, The Roosevelt I Knew, 144.

1. H.W. Brands, Reagan: The Life (New York: Anchor Books, 2016), 405.

2. Ronald Reagan, "Remarks at the Annual National Prayer Breakfast," 3 February 1983, The American Presidency Project.

3. Smith, Faith and the Presidency, 330.

4. Wirthlin with Hall, The Greatest Communicator, p. 100; Ronald Reagan, "Diary Entry," 10 April 1981, White House Diaries.

5. Ronald Reagan, "Address Accepting the Presidential Nomination at the Republican National Convention in Detroit," 17 July 1980, The American Presidency Project.

6. Michael K. Deaver, A Different Kind of Drummer: My Thirty Years with Ronald Reagan (Harper Collins, 2001), 3.

7. Ronald Reagan, “Address Before a Joint Session of the Congress on the Program for Economic Recovery \#2," 28 April 1981, The American Presidency Project.

8. Roosevelt, "Inaugural Address"; Ronald Reagan, "Election Eve Address 'A Vision for America," 3 November 1980, The American Presidency Project.

9. Hanska, Reagan's Mythical America, 26; Erickson, Reagan Speaks, 86-87.

10. A plausible explanation is that America in 1981 was less pious than America in 1933. It had become "secularised." What is more, religion, in particular Christianity, had retreated from the mainstream and been associated with evangelism - an important but nonetheless fringe movement in the culture. See Walter Sundberg, "Religious Trends in Twentieth-Century America," Word \& World XX, no. 1 (Winter 2000), 22-31.

11. Reagan, "Address Accepting the Presidential Nomination."

12. Ibid.; Roosevelt, "Address Accepting the Presidential Nomination."

13. Reagan, "Election Eve Address."

14. By characterising himself much the same way as his Democratic hero, Reagan, Kazin explains, was able to win over a portion of white Democrats. See Michael Kazin, The Populist Persuasion: An American History - Revised Edition (Ithaca: Cornell University Press, 1998), 261.

15. Reagan, "Election Eve Address."

16. Reagan, "Address Accepting the Presidential Nomination."

17. Ronald Reagan, "Address Before a Joint Session of the Congress on the Program for Economic Recovery \#1," 18 February 1981, The American Presidency Project; Reagan, "Election Eve Address."

18. Reagan, "Address Accepting the Presidential Nomination."

19. Reagan, "Address on the Program for Economic Recovery \#1." 
20. Ronald Reagan, "Address to the Nation on the Economy," 5 February 1981, The American Presidency Project; Ronald Reagan, "Address to the Nation on Federal Tax Reduction Legislation," 27 July 1981, The American Presidency Project.

21. Reagan, "Address on the Program for Economic Recovery \#1."

22. Roosevelt, "Inaugural Address."

23. Reagan, "Address to the Nation on Federal Tax Reduction Legislation."

24. Reagan, "Inaugural Address."

25. Liberty was a central term for Reagan. See Wirthlin with Hall, The Greatest Communicator, 93.

26. Reagan, "Election Eve Address."

27. Reagan, "Address Accepting the Presidential Nomination."

28. Reagan, An American Life, 219.

29. Smith, Faith and the Presidency, 338.

30. Reagan, An American Life, 219.

31. 1980 Campaign Plan, folder "[Reagan for President Campaign Plan 6/29/80 (Draft)]," box 177, Richard Wirthlin - Political Strategy, Ronald Reagan 1980 Presidential Campaign Papers, Ronald Reagan Library, 33.

32. Garry Wills, Lead Time: A Journalist's Education (Boston: Mariner Books, 2004), 261, 263.

33. Robert N. Bellah, "Civil Religion in America," Daedalus, Vol. 96, No. 1. (Winter 1967), 18.

1. For a reminder, Obama had suggested it is to "give a sense of unity and purpose and optimism" to the people in crisis-ridden junctures. See Boerma, "Obama Reflects."

2. Quoted in Salmon, Storytelling, 85.

3. Roger Stone, "Nixon's Dirty Trickster," Breaking the Set, RT, 4 November 2013.

4. Salmon, Storytelling, 87-88.

5. Hayden White, The Content of the Form: Narrative Discourse and Historical Representation (Baltimore: The John Hopkins University Press, 1987), 1.

6. Jonathan Gottschall, The Storytelling Animal: How Stories Make Us Human (Boston: Mariner Books, 2013), xiv.

7. Martin Scorsese in A Personal Journey with Martin Scorsese Through American Cinema, directed by Martin Scorsese and Michael Henry Wilson (London: BFI, 1995).

8. Quoted in Greer, What Roosevelt Thought, 112.

9. This is taken from an oft-quoted remark by Reagan: "An audience has a feel to it and, in the parlance of the theater, that audience and I were together." Quoted in Dallek, Ronald Reagan, 18.

10. Ralph E. Weber, ed., Letters from the Desk of Ronald Reagan (New York: Broadway Books, 2005), Introduction.

11. Alter, The Defining Moment, 184-187, quote 185.

12. Ibid., 59.

13. Curt Smith, The Presidents and the Pastime: The History of Baseball and the White House (Lincoln: University of Nebraska Press, 2018), 284-285, quote 285.

14. Deaver, A Different Kind of Drummer, 83.

15. Frances FitzGerald, Way Out There in the Blue: Reagan, Star Wars and the End of the Cold War (New York: Touchstone, 2001), 15.

16. George P. Shultz, Turmoil and Triumph: My Years as Secretary of State (New York: Charles Scribner's Sons, 1993), 1133.

1. Oral History with Perkins, part IV, pp. 30-31.

2. Wirthlin with Hall, The Greatest Communicator, 113.

3. Gil Troy, Morning in America: How Ronald Reagan Invented the 1980s (Princeton: Princeton University Press, 2005), 53. 
4. Presidential Briefing, 15 January 1981, folder "First 90 Days, Presidential Briefing," box 7 OA 12390, Richard S. Beal Files, Office of Planning \& Evaluation, Ronald Reagan Library.

5. Strategic Evaluation Memo, "Franklin D. Roosevelt," undated, folder "SEM, State of the Union Messages," box CFOA 188, Richard S. Beal Files, Office of Planning \& Evaluation, Ronald Reagan Library.

\section{ABSTRACTS}

This article investigates the rhetoric of Presidents Franklin D. Roosevelt and Ronald Reagan when they took office, in 1933 and in 1981, at two moments of crisis. More specifically, it compares and contrasts the stories the two presidents told the American people through their speeches. It finds that the stories had strong parallels: Roosevelt and Reagan both depicted America as a land in decay, and portrayed themselves as messiahs who would redeem the nation. Ultimately, this article argues that the presidents both used story as strategy. That is to say their stories had a political endgame. Indeed, Roosevelt's and Reagan's messianic stories were tools to help transform American political ethos, and in so doing foster support for their reform agendas.

\section{AUTHOR}

\section{THEO ZENOU}

Theo Zenou is a PhD candidate in American history at the University of Cambridge, working on JFK, leadership and the Cold War. 